\title{
Barroquismos em cordéis de testemunho: migrações, massacres e resistências nos sul e sudeste do Pará - Brasil
}

\author{
Hiran de Moura Possas*
}

\section{Preâmbulo}

Os exercícios descritivos acompanhados de ensaios interpretativos, a partir de escutas iniciadas em 2015 com as vozes e as literaturas "subalternas"1 da cidade de Marabá/PA, desconheciam, talvez por subestimar, a faculdade de "tender-distender, contrair e dilatar [...] envolver-desenvolver, involuir e evoluir" (Deleuze, 1991) dessa dobra comumente batizada de folheto de cordel. A mera oposição oral/escrito não nos coube, como parâmetro, nessas experiências pelo sul e sudeste do Pará.

Essa tentativa de acompanhamento e de análises dos barbantes físicossimbólicos que sustentam esse(a)s escritos/vozes da Amazônia Oriental paraense têm significado algumas escolhas. Essas "cordas", inclusive as vocais, não estiveram dispostas linearmente a nossa espera. Estavam e ainda estão embaraçadas seguindo um fluxo que, hipoteticamente/geometricamente, representaríamos com as estruturas e subestruturas dialéticas de uma espiral.

Fizemos, aqui como epicentro dessa estrutura espiralizada, os ecos-escritos de maior afecção ao grupo de pesquisadores. Aqueles, às vezes veladamente, recontando narrativas para a luta pela terra e à guerrilha do Araguaia. Passado se fazendo presente de quem Foucault (2003) chamaria de "homens infames" ou existências sufocadas por discursos tentando regular o que mereceria ser história e o que deveria ser esquecido. Aqui, sujeitos culturais que, por sua força criativa, capazes de transformar suas memórias em máquina dionisíaca de destruiçãoreconstrução dos sentidos e das histórias mais habituais.

\footnotetext{
Doutor em Comunicação e Semiótica e professor da Faculdade de Educação do Campo e coordenador do Programa de Pós-Graduação em Dinâmicas Territoriais e Sociedade na Amazônia, Universidade Federal do Sul e Sudeste do Pará, Brasil. E-mail: hiranpossas@gmail.com.

1 Provocados por Spivak (2010, p. 60), utilizamos a categoria analítica para a realização de estudos com as artes "marginais" e a sua "difícil tarefa de reescrever suas próprias condições de impossibilidade como as condições de possibilidade".
} 
Nesse preâmbulo, faremos pertinente descrição das premissas metodológicas para acesso ao intenso e embaralhado tráfego de "barbantes" à região sul e sudeste do Pará: foi realizado levantamento bibliográfico de literatura acadêmica existente acerca de poéticas da voz, bem como aportes teóricos relacionados à pesquisa etnográfica e à história oral, mais detidamente ligadas a tentativas de descrição ou mesmo "conexão entre campos semânticos e também etnográficos - heterogêneos" (VIVEIROS DE CASTRO, 2006, p. 1) e à realização de entrevistas pensadas como diálogo ou experiência de encontro de perspectivas, sem grandes roteiros ou estruturações prévias. Uma tentativa de comunicação entre culturas - desvelando memórias, fenômenos materiais, corpóreos e psíquicos. Esse material, após leitura e reflexão com os integrantes do projeto, nos posicionou, em certa medida, para o trabalho de campo em busca do maior número possível de folhetos de literatura de cordel acompanhados de gravações com as autorias. Em fase posterior, foram realizadas análises dessas gravações e dos folhetos, destacando-se como temas mais recorrentes: narrativas sobre a guerrilha do Araguaia; a exploração e rapinagem humana nos garimpos e nas fazendas, além daqueles, cujo mote de seus discursos gravitava sobre a luta pela terra.

Dessa experiência com barbantes e vozes, desejamos "tracejar" o que chamaremos, como o empréstimo de Agamben (2009), em mediações com Michel Foucault, "contra dispositivos". ${ }^{2}$ Um experimento relacional opondo-se ao nosso ainda "inconsciente acadêmico", manifestando ideias ancoradas em categorias "desbotadas", como "essência" ou "ser" (Glissant, 2005). Seria um desejo 3 potencializando uma tentativa de rompimento com "las conexiones preexistentes para poder manejarnos desde un estrato amorfo a la búsqueda de nuevas articulaciones que nos repongan una visión más coherente y a la vez más identificada con la creación” (RAMA, 1982, p. 43).

Há, desse modo, um número imensurável de poéticas de vozes e barbantes entranhadas nos distritos, cidades, assentamentos e acampamentos próximos à cidade de Marabá. ${ }^{4}$ Socorridos pelas poéticas topográficas de Calvino (199o, p. 44), faremos, pelo limite desse espaço, descrições e breves análises desses encontros e dessas texturas:

2 O termo, aqui usado, especialmente a partir de Giorgio Agamben (2009), quando o pensa como uma função estratégica e concreta se inscrevendo sempre nas relações assimétricas de poderes.

3 Desejo, semanticamente, em compasso com Deleuze em suas mais diversas reflexões. Não seria sinônimo de falta ou de carência de algo, como bem quis impor os sentidos dos discursos de contornos cristão, mas construção de novos arranjos ou novos agenciamentos.

4 Pela história dos homens eurocentrados, Marabá foi germinada, primeiramente pelas mãos de homens advindos da região nordeste, afugentados, já no final do século XIX, pelos conflitos sangrentos do coronelismo. A intenção desses pecuaristas, vaqueiros e também agricultores era descobrir campos naturais, supostamente existentes nas cabeceiras do rio Itacaiunas. Sertanistas natos realizaram, de certa maneira, etnografia das paisagens naturais e humanas, resolvendo instalar suas famílias em espaços, por eles denominados de "burgos" (PossAs et al, 2016, p. 2-3). 
As cidades são como os sonhos, são construídas por desejos e medos, ainda que o fio condutor de seu discurso seja secreto, que as suas regras sejam absurdas. Cada território estético-geográfico em destaque sem hierarquizações - liberta dos policiamentos discursivos a verdade dos loucos. ${ }^{5}$

\title{
"Lorotas" da Guerrilha do Araguaia
}

Manoel de Sousa Rodrigues, o "Manoel Lorota" nasceu "no Tocantins, numa tal de Araguanorte, perto de Ananás e de Santa Isabel, em 16 de junho de 1966" (Lorota, 2016). Migrou para a região de Palestina do Pará, ${ }^{6}$ mais tarde, com 20 anos de idade. Vive da comercialização do peixe e faz questão de frisar por suas falas "versificadas" que sempre desempenhou trabalhos que exigissem força física. Desde menino, tem esse repente de fazer versos, daí "os craba me chamar de Manel Lorota. E aí ficou" (LoROTA, 2016). Já foi muito "bebedor" e pela rua as pessoas sempre faziam desafios: "Aí diziam assim, 'olha o Manel Lorota está calado, será que ele não fala?' Aí eu era obrigado a fazer um verso e falar pra eles” (LoRotA, 2016).

\author{
Meu nome chama Manel \\ Filho da gasolina \\ Eu nasci e me criei no posto da Palestina \\ Vivo sofrendo muito \\ Cachaça não me domina \\ Vivo da pescaria que toda vida foi minha sina \\ Desde menino vivo de trabalhar \\ Sofrendo na juquira não tendo o que falar (LoROTA, 2016). ${ }^{7}$
}

Lorota, de certa forma, "força" os estudos monolíngues a pensarem com os pés, se fosse razoavelmente possível descrever um poeta que viveu uma relação de amor-ódio com a cachaça. A Palestina do Pará é um "lugar manso para se viver". Essa seria uma das paisagens culturais da região Amazônica que testemunhou e persiste em ecoar, mesmo pelas vias mais subterrâneas, os confrontos entre guerrilheiros e militares, em solos da Guerrilha do Araguaia.

Lorota obedece certa "regra" da cidade. Pouco fala, contrariando sua personalidade, quando é provocado a versar sobre a Guerrilha: "Não! Sobre isso eu não tenho nenhuma, naquele tempo eu já era gente, mas só que eu não lembro

5 Também tomamos por empréstimo a reflexão de Michel Foucault (1996) em "A ordem do discurso".

6 Município da região Sudeste do estado do Pará, às margens do rio Araguaia. Sua população estimada em 2016 era de 7.404 habitantes. Possui uma área 984,362. Fonte: IBGE. Segundo narrativas de seus moradores, a escolha do nome "Palestina"seria relacionada ao fato de que a maioria dos colonos ali chegados ser de origem cristã-protestante. Com uma visão fortemente religiosa, eles enxergavam naquelas terras uma extensão das promessas bíblicas dadas ao povo hebreu sobre a Canaã Palestina, uma "terra de onde mana leite e mel".

7 Os versos foram recitados, na entrevista referenciada na bibliografia desse artigo. 
(LOROTA, 2016)". Por outro lado, o poeta da Juquira demonstra uma memória elástica quando recita Patativa do Assaré: "Eu tenho uns versos assim, de romance. Uma história de um cantor. Uma cabra que disse que era rico e tinha um Padim Cicero e ele pediu um tostão de chuva. Eu sei o romance todinho" (Lorota, 2016).

\author{
No sertão do Cariri \\ Certo tempo um fazendeiro \\ fez uma carta a meu padrinho \\ E mandou por um romeiro \\ Comprando um tostão de chuva \\ Ao padre do Juazeiro \\ Dizia a carta citada \\ Seu padre Cícero Romão! \\ Dizem que és milagroso \\ Cumpra a sua obrigação \\ Me mande um tostão de chuva \\ Pra aguar minha plantação (LOROTA, 2016).
}

Tentando libertação das análises mais apressadas, especialmente as canhestras, Lorota nos pareceu um "fingidor", como Fernando Pessoa. O poeta em suas várias versões, ao buscar uma metáfora do mundo da construção civil, dá contornos àquele que trolha, imitando com a colher no cimento a escultura em pedra, especializado na arte de decorar fachadas. O trabalho em cimento e gesso imitava com perfeição a escultura em pedra. Arriscamo-nos a dizer que o verso dito popular é fazer estético também de fingidores: um linguajar "rústico", sem ambições metafóricas, de um lirismo recatado, de emoções partilhadas com batidas simples, tais o ritmo dos passos de um peregrino ou o bater do coração (FrEIRE, 2014). Os versos de Lorota são "recriados" pelas frequentes escutas e experimentações na Juquira. Coladas aos versos de Patativa, as lorotas do Lorota são signos em contágios múltiplos desafiando os aprisionamentos das autorias. Marginalidade ${ }^{8}$ procurando, quando possível, driblar as armadilhas da repetição e da rendição classificatória. Desejo agônico de girar os significados despojando o signo dos seus sentidos habituais. Procura insistente pela germinação por/de outros campos semânticos:

Essa mão que move as arestas, os espelhos as faces dos verbos movemse com cautela, apesar de impor-se inquieta e persistente; incontrolavelmente insatisfeita. Em sua faina, tudo que ressoe a significado conta. Todas as maneiras de dizer o verso, qualquer impostação vocabular. Tudo ao derredor participa de sua lavra, de sua fortuna poética para que se conjugue à colheita a diversidade e o múltiplo. Forma, disposição da grafia, cor, ritmo, sonoridade, disjunção e conjunção de elementos significativos,

\footnotetext{
Seguindo as impressões de Slavoj Zizek (2002): ser marginal hoje em dia faz parte da cultura dominante, não é algo automaticamente subversivo. Ser marginal não quer dizer que se é marginal, mas sim uma maneira de determinar sua posição, que na verdade pode ser bem central.
} 
o espacejamento que se dota de valor, a palavra em sua integridade ou o fragmento, às vezes farrapos de palavras, prefixos que ganham o mundo sozinhos desmembrados de seus radicais (Tupiassú, 2000: [s.n]).

Cabe reflexão sobre essa "prodigiosa" e, ao mesmo tempo, "precária" memória de Lorota. Ele demonstra sobre a Guerrilha certa clareza do que acontecera, pois “já era gente", mas prefere não narrar sob a justificativa de que só agora soube que "aquele movimento todo tinha nome de guerrilha". Para ele tratava-se, nas suas lembranças de criança bem crescida, de "movimento estranho de gente diferente [...] gente do mato e uniformizados".

\author{
Por isso que eu falo prus meus amigos \\ O começo da minha memória \\ Só que eu não quero voltar \\ Quero viver o que vivo agora (LOROTA, 2017).
}

Como boa especulação de nossa parte, o gesto testemunhal "de certo modo só existe sob o signo de seu colapso e de sua impossibilidade" (SElligmann-Silva, 2008, p. 67). Esse fato inenarrável nos parece desdobramento da impossibilidade de se descrever um testemunho lúcido de um fato geralmente reservado para os porões do esquecimento. O testemunho de Lorota sobre a guerrilha pode ser especulado por outro tema recorrente de seus versos: "a demanda com a cachaça e o fumo". Lorota atribuiu à cachaça um importante mecanismo para guardar na memória suas aventuras e desventuras na Juquira. Concomitantemente, seus versejos para o álcool referendam possíveis lapsos memoriais: "rapaz, é ruim quando a gente esquece as coisas, erra demais, o bom é se fosse uma coisa sem erro" (LOROTA, 2016).
Um casal que veio ao mundo só para fazer desgraça
Se apossando da matéria traz doença e faz miséria
E péssimo vício não passa
O fumo com a cachaça se encontraram na feira
Ele calma e paciente ela muito a vuaceira
Aí fizeram um juramento, fizeram um casamento
Numa mesa de bebedeira (LoROTA, 2016).

O trauma, seja ele pela experiência com aquele movimento estranho (a guerrilha) e/ou com a cachaça, encontra no território da imaginação a combustão necessária para revelar um importante testemunho.

Concluindo, gostaria apenas de lembrar que não existe a possibilidade de se estabelecer uma fronteira entre a ficção e, por outro lado, a confissão e o testemunho. Do mesmo modo, testemunho e confissão também são assombrados pela possibilidade de mentira. Como vimos, Riobaldo mesmo já desconfiava de que 
seu interlocutor achava que o que narrava era falso. Derrida foi um dos pensadores que melhor formulou estas ideias: "uma confissão não tem nada a ver com a verdade"," uma circonfissão é sempre simulada", ele sentenciou. E ainda constatou: "[O] testemunho tem sempre parte com a possibilidade ao menos da ficção, do perjúrio e da mentira. Eliminada essa possibilidade, nenhum testemunho será possível e, de todo modo, não terá mais o sentido do testemunho" (SELIGMANNSilva, 2008, p. 146).

As "lorotas" de Lorota são infindáveis. Cabe breve reflexão sobre certo trecho de sua entrevista:

No tempo de política, eles vêm. Eu faço de um lado e falo do outro. Sabe como é política, né? Mas eu faço só por fazer, não vou lá cantar não, porque às vezes assim eles ficam com raiva da gente, aí eu faço eles vêm aqui e pegam, levam, gravam e cantam pra lá (LOROTA, 2016).

O poeta-cantador é muito requisitado nos períodos de eleição. Estrategicamente não tem posicionamento político. Nesse contexto assemelha-se - isso em um ensaio interpretativo bem inicial - aos trickster:

o trickster raramente tem morada fixa, perambulando pelos espaços sociais, naturais e sobrenaturais com notável desenvoltura [...] é espírito sem lar, errante, frequentador dos mercados, das encruzilhadas, das fronteiras (Queiroz, 1991, p. 04).

Outro aspecto relevante da poética de Lorota gravita pelo "acordo coletivo improvisado" quando assistimos às performances do pescador de versos, na Palestina do Pará. O tempo do desafio demonstra a competência e o saber-fazer malabarismos ou algazarras com diferentes linguagens. Lorota, desafiado, articula rimas improvisadas com gestos, expressões, olhares, sorrisos e lamentos. Ele lamenta não ter acesso ao suporte escrito para "dar mais vida" para sua arte. Recepcionar essa "multidão" textual não nos significou decantar de cada linguagem temáticas para uma análise. Pelo contrário, as rimas, por exemplo, nasciam também dos olhares perdidos, dos sorrisos irônicos e da brevidade do nosso encontro:

\footnotetext{
Nessa trava popular se a poesia der chance

Dentro da bola do mundo

Eu vou dar um grande lance

Fazendo minhas poesias

O que eu via em profecia

E o que está no meu alcance

Dizia meu padrim Ciço

Na matriz do juazero
} 
Que o povo chegava ao fim

Por causa do desespero.

$[\ldots]$

Mas eu lhe falo a verdade

A gente quase nem tem valor

Se ser obrigado eu vou de novo

Pois é a vida do pescador (LOROTA, 2017).

Pescador, contador de "causo" e sobrevivente da Guerrilha do Araguaia, Mestre Lorota transita pelos mundos semióticos, promovendo exercícios escriturais a partir da voz. Seus versos são conglomerados ambulantes de falas estendidas sobre muitas superfícies, não havendo nesse contágio intersemiótico a primazia ou a superioridade de uma das partes de sua simbiose artística.

\section{Barbantes de cordéis da boca da noite}

A memória de "Seu Poeta" guarda significativa elasticidade para massacres e lutas pela terra, principalmente ao descrever com detalhes, ausentes dos circuitos históricos mais comuns, a ocupação da Fazenda Rio Branco em 1994, hoje Projeto de Assentamento Palmares II. A comunidade localiza-se a $20 \mathrm{~km}$ do município de Parauapebas - PA, com 15 mil habitantes. Atualmente, a comunidade possui associações, feira, posto de saúde, várias igrejas, grandes comércios, cooperativas de vans e quatro escolas. Há uma grande produção de gado, leite, galinha, arroz, feijão, hortaliças, vegetais e frutas para sustento próprio das famílias, sendo o excedente comercializado em Parauapebas.

"Seu Poeta" chama-se Edimar Moreira e em diálogos tenta construir uma linha do tempo para descrever sua vida. Costuma "costurá-la" com mais detalhes quando do encontro e participação no MST (Movimento Sem Terra):

Olha, a minha história de vida, algo que fez chegar até aqui, no estado do Pará e junto ao Movimento Sem Terra, eu vim do estado do Maranhão. É, migrei pra Jacundá. Lá, tive quatro anos e não gostei da região. E aí divido essa fofoca de emprego em Parauapebas, uma coisa que todo mundo corria praí. Aí em 93 eu vim pra Parauapebas, que a realidade era diferente do que se falava lá, emprego tinha, mas pra quem era profissional, como eu não tinha profissão, se tornou difícil. Já em 94, o Movimento Sem Terra fez essa movimentação em Parauapebas, acampamento e tudo pra ocupar uma área aí, e eu achei que o caminho era ali. Então decidi me acampar, e tô aqui até hoje (Seu Poeta, 2017).

Migrante nordestino atraído pela "fofoca de emprego", Seu Poeta, já no então acampamento na Fazenda Rio Branco, rememora, performaticamente com gestos agônicos de tristeza e lamento as notícias do Massacre de Eldorado de Carajás, 
Nós tava no acampamento no dia que, inclusive era pra mim ir pra aquela jornada do massacre, mas como nós tava no processo de tirando uma lenha pra, pro zé de área pra recardando recurso pros justamente pros que iam pra marcha, e aí eu fiquei nesse grupo que ficou aí, trabalhando aqui, não fui pro massacre. Tivemos a notícia, soubemos a boca da noite, mais ou menos sete horas da noite, chegou a noite no acampamento do massacre. [seu Poeta parou, ficou com um semblante triste e continuou em seguida]. Ah muita tristeza! Passamos por muita, muita revolta, muita tristeza, porque a gente ver acontecer um. Um massacre daquele, com tantas pessoas que tavam sonhando em ter um pedaço de terra, igual hoje eu tenho, muita gente que tem né, infelizmente foi quase de desanimar todo mundo, mas a luta continua... [voz baixa] (Seu Poeta, 2017).

Suas lembranças refratam as estratégias daqueles que cometeram a barbárie. A boca da noite seria o tempo e o espaço da vulnerabilidade. As vítimas acampadas na Curva do $S$ estavam na escuridão e, naquele momento, desprotegidas pelo reduzido número. A notícia abateu Seu Poeta e companheiros, mas como sinaliza, parece existir no movimento uma pedagogia da continuidade e do recomeço pelas ruínas, apesar de tristeza e da revolta. Não há, para Seu Poeta, mínima possibilidade de reforma agrária sem movimentos sociais. Seriam processos indivorciáveis, ainda que para as interpretações mais apressadas, isso seja associado e restrito às políticas públicas.

O cordel, na vida desse peregrino ativista, surgiu pelo hábito de confeccionar diários. Ele precisava guardar e relatar os acontecimentos e sabia que mais tarde os mais novos também precisariam conhecer essa história não revelada ou sonegada:

Olha, na época que a gente tava acampado, era muita, era muita coisa, muita, muitos acontecimentos e eu achei que aquilo não podia ficar em branco. Sem ficar aquilo inscrito pra que, alguém que não tivesse naquela luta, depois tivesse conhecimento. E aí eu decidi tá escrevendo um, a cada conhecimento que ia acontecendo eu tava escrevendo e no final, quando foi realizado o assentamento, o movimento, como eu tava com aquilo escrito no caderno, aí o movimento mandou publicar ainda duas mil cópias. É porque aquele cordel, é, ele é uma história contada o que existe ali é somente o que aconteceu. E ela, eu decidi contar ela em, em versos e cordel, porque eu desde criança, lá no Nordeste eu admirava muito aqueles caras que cantavam aqueles repentes em literatura de cordel, aí eu era muito, criança mermo e aí eu decidi contar em cordel (SEu Poeta, 2017).

Os barbantes que sustentam essa poética não conseguem dissociar a letra da voz. Quando criança esse artista alimentou admiração pelos repentistas, mas sabia que essas histórias não poderiam se perder pelas performances momentâneas. Soube que o folheto se tornava, em certo sentido, um guardião desses testemunhos:

E foi pela necessidade que tinha de aquilo ali ser registrado dos acontecimentos. E aí eu achei que se não tivesse alguém pra escrever aquilo 
que tava acontecendo, pra depois ficar de lembrança, hoje ninguém saberia como tinha acontecido num assentamento tão bom desse, podia achar que era só maravilha, só... então por isso eu decidi escrever. Eu comecei no início, quando a gente começou a se reunir pra ocupar a área, durante o tempo que a gente tava ocupados a área, durante o despejo, as, a ocupação do Incra. A ocupação, de praça pública de Parauapebas, e aí eu ia escrevendo a cada momento. Quando eu parei de escrever como está escrito nele lá, quando a terra tinha desapropriada, que a gente já tinha certeza que a terra era nossa. E os temas abordados eram esses: os conflitos as negociações, viagem pra Brasília, as ocupações do Incra, era cada acontecimento eu registrava o que foi acontecido durante aquele dia (Seu Poeta, 2017).

Seu Poeta nos compartilhou um sonho: "tenho um sonho de publicar uns livros de poesia [...] eu agora entrei com a minha aposentadoria rural e a hora em que eu conseguir aposentadoria, vou também diminuir o serviço na roça, eu vou me dedicar a escrever um livro". Seus escritos estão guardados, memórias vivas da luta pela terra sob a forma de cordel e também de músicas. Mais prazeroso para o artista, porém, sempre será a recepção de seus escritos ou de suas recitações: "A partir de quando eu comecei a escrever, eu apresentei em assembleia o trabalho que eu ia fazer da história do assentamento, aí todo mundo gostou e na assembleia já tiraram por decisão mim apelidar de poeta [...] ei, esse é o poeta, esse é o poeta, aí pronto" (SEu Poeta, 2017).

\section{Fé nos movimentos sociais}

Silvandira Martins Ferreira nasceu no Município de São Geraldo do Araguaia, estado do Pará, em 1977. Com três anos de vida chegou à Cidade de Brejo Grande do Araguaia-Pará. A família veio atraída pelo desejo de conseguir terra. Desde os sete anos, participa de movimentos sociais, no princípio pelo MAC-Movimento de Adolescentes e Crianças. Footnote 10 ONG fazendo parte do Movimento Internacional de Apostolado das Crianças - MIDADE - MIDADEN - MIDAC - IMAC, com sede em Paris - França, e presente em 52 países.

Foi a partir daí que Silvandira começou ao que chama desejo de dar vazão "a uma forma da gente se expressar [...] um grito. Uma forma de revelar, desabafo" (Silvandira, 2016). Dentre suas composições, destacam-se as músicas, os hinos e os cordéis dedicados à sua militância na Pastoral da Criança. Representa-se como camponesa, hoje residindo no Assentamento Castanheira II, ${ }^{9}$ próximo à Comunidade Santa Rita, na cidade de Brejo Grande do Araguaia.

Tem um fato que me assusta

Me dá medo com certeza

9 Projeto de assentamento de 1998, de mais de 120 famílias, desapropriação de uma fazenda de 960 alqueires. 
São os venenos brutos

Que jogam na natureza.

Os médicos mandam comer verduras

Mas tá tudo envenenado

Como fica nossas crianças, idosos e jovens

Consumindo alimentos contaminados

$[\ldots]$

O homem e a terra são casados

Formam um único casamento

Como pode ele agora.

Causar tanto sofrimento? (Silvandira, 2016). ${ }^{10}$

Pela pena de Silvandira situações cotidianas dos assentamentos da região vem à tona. $\mathrm{O}$ assentamento é cercado de atividades do agronegócio, o que diretamente afeta a vida dos moradores. Água contaminada e as doenças causadas por seu consumo, além das pressões, às vezes violentas, aos camponeses.

Em seus cordéis, Silvandira vê a oportunidade de criar "uma memória para sua comunidade". Junto às vozes da experiência da região, metonimicamente, o assentamento pulsa pela boca dos moradores. Destaca-se, dentre tantas histórias, a saga pela construção da igreja, um espaço não só estratégico para a multiplicação da fé religiosa, como da formação política de camponeses engajados e conscientes de sua missão: a luta infinita pela terra.

\author{
Mas a luta não parou \\ Começou o mutirão \\ Pra construir a igreja \\ Casa de encontro com os irmãos \\ Pra ouvir a palavra de Deus \\ E seguir firme na missão. \\ $[\ldots]$ \\ A missão não é só minha \\ A missão é de todos nós \\ Abrace a luta você também \\ Jamais cale a voz (SILVANDIRA, 2016).
}

Silvandira é performática a seu modo. Longe de um corpo efusivo, vai "manducando" a palavra. Escritura-corpo contida, mas superfície artística fruto de discretos espasmos musculares reagindo na interação dos seus intérpretes e ouvintes. Em conjunção com a sua voz quase inaudível, seus pequenos gestos checam e convidam, em princípio, à audição: "[...] a língua do gesto é também a do sopro, ela provoca uma espécie de reserva pré-linguística [...]" (ZumTHoR, 1993).

\footnotetext{
${ }_{10}$ Os versos foram recitados na entrevista.
} 


\title{
Massacres e migrações
}

Valdir de Araújo é filho de migrantes vindos do nordeste brasileiro em busca de terras e ouro, no sudeste paraense. Ele ou sua história de vida tematiza a trajetória do homem do campo e do agricultor.

É melhor pra gente falar porque a gente tá aqui, a gente conhece [...] ninguém melhor pra falar, do que a gente que conhece, é a história de um, é a história de outro e todo mundo quer saber [...] (Araújo, 2016).

O pai de Valdir veio para a região no início da década de 1970, atraído pelo ideário de que aqui encontraria terras para fazer morada e plantar sua roça, chegando ao município de São João do Araguaia, lugar de nascimento do poeta. Sua família não concretizando o sonho do Eldorado ou, pelo menos, de dispor do tal pedaço de chão, logo mudou-se para Marabá. Sem demorar muito, o pai do poeta, junto de familiares, expandiu seus rizomas a Brejo do Meio, graças à militância junto ao Movimento Sem Terra. O poeta conta com orgulho sua busca pela formação acadêmica. Orgulhosamente, hoje em dia, é colega de trabalho de alguns de seus antigos professores.

Desde criança, acompanhava a família e os vizinhos contarem histórias ao redor dos acampamentos erguidos na luta pela terra. Seus cordéis são alimentados dessas vozes "ruminando" sua memória. Como sempre gostou de escrever, deixava tudo guardado no "baú", mas vencido pelo desejo de fazer aquelas vozes alcançarem outras pessoas, resolveu trazê-las de seu arquivo estratégico. Dele, lavradores, agricultores e camponeses narrativizam testemunhos de alegria, perdas, violência e desesperança.

Valdir Araújo também verseja pelo campo sagrado e minado da Guerrilha do Araguaia. Jovens cansados e feridos chegavam em comunidades em volta do rio Araguaia solicitando ajuda. Sem compreender quem eram aqueles estranhos e pelo que lutavam, os moradores prestavam solidariedades. Por outro lado, caso não colaborassem com o arsenal bélico do exército montado na região, eram torturados, mortos e acima de tudo, resignados a uma não existência em cemitérios clandestinos:

\author{
Corpos foram sepultados \\ No município de Xambioá \\ Ossadas também encontradas \\ No solo de Marabá \\ Outros presos nas vilas \\ Nunca sabemos onde está (ARAÚJo, 2016).
}

Dos perseguidos, um em especial está "tatuado" nas vozes que alimentam os cordéis de Valdir Araújo: o gigante Osvaldão. 
Bacharel em direito

Treinado no exército chinês

Osvaldão em guerrilheiro

Autêntico logo se fez,

E com tática cubana

Armou o povo de vez

$[\ldots]$

Na floresta paraense

Osvaldão se refugiou

De Palestina a São Geraldo

As matas ele explorou

$[\ldots]$

Os escudeiros de Osvaldão

Logo foram prendidos,

Então delataram ao poder

Onde o chefe tava escondido

Numa campanha de guerra

Osvaldão foi surpreendido (ARAúJo, 2016).

Essa memória do cordelista dá guarita a dispositivos que operam por fluxos temporais dissimétricos e coexistentes. A memória não se restringindo a uma versão única e linear dos fatos, mas sim uma rapsódia por seu caráter múltiplo, difuso e caótico, ramificando-se e desdobrando-se de formatos magmáticos, a partir de uma interconexão de múltiplos planos temporais, que inclusive também se contradizem (HuR, 2013, p. 181).

Os movimentos das memórias, pelos cordéis de Valdir, são tão sinuosos e às vezes imprecisos que acabam por impor uma certa ressignificação da arte. Poética oral ou cordel? Compreendemos esses experimentos como a astuciosa estratégia da oralidade a procura de outras territorialidades. Seria a ressurgência de energias vocais da humanidade, reprimidas durante séculos no discurso social das sociedades ocidentais pelo curso hegemônico da escrita. Os signos dessa ressurgência (melhor dizer insurreição?) estão em toda parte procurando novas hospedagens reveladoras de barbáries (ZUMTHOR, 2000, p. 15).

\section{Imanências por escutas}

Tanta criatividade e imprevisibilidade testemunhadas no encontro com as poéticas supracitadas nos impedem exercícios classificatórios. Isso seria desconsiderar por completo a crítica dos barbantes preferindo o silêncio. Na construção de um ensaio interpretativo para os versos e temáticas arrolados: sobreviventes de uma sociedade nazifascistoide - de máscaras democráticas, mas de pele fascista - os artistas subalternos sobrevivem diariamente aos soft golpes diários impostos, 
tentando determinar e ferir seus desejos (RoLNIK, 2014). De certo, apesar da condição de penúria de alguns descritos, há uma rebeldia incompreensível e até mesmo indescritível. Algo como a murta vieiriana "incomodando" o desejo de propagação de fés, como àquelas no Sermão do Espírito Santo.

Os que andastes pelo mundo, e entrastes em casas de prazer de príncipes, veríeis naqueles quadros e naquelas ruas dos jardins dois gêneros de estátuas muito diferentes, umas de mármore, outras de murta. A estátua de mármore custa muito a fazer, pela dureza e resistência da matéria; mas, depois de feita uma vez, não é necessário que lhe ponham mais a mão: sempre conserva e sustenta a mesma figura; a estátua de murta é mais fácil de formar, pela facilidade com que se dobram os ramos, mas é necessário andar sempre reformando e trabalhando nela, para que se conserve. Se deixa o jardineiro de assistir, em quatro dias sai um ramo que lhe atravessa os olhos, sai outro que lhe descompõe as orelhas, saem dois que de cinco dedos lhe fazem sete, e o que pouco antes era homem, já é uma confusão verde de murtas. Eis aqui a diferença que há entre umas nações e outras na doutrina da fé. Há umas nações naturalmente duras, tenazes e constantes, as quais dificultosamente recebem a fé e deixam os erros de seus antepassados; resistem com as armas, duvidam com o entendimento, repugnam com a vontade, cerram-se, teimam, argumentam, replicam, dão grande trabalho até se renderem; mas, uma vez rendidos, uma vez que receberam a fé, ficam nela firmes e constantes, como estátuas de mármore: não é necessário trabalhar mais com elas. Há outras nações, pelo contrário - e estas são as do Brasil -, que recebem tudo o que lhes ensinam, com grande docilidade e facilidade, sem argumentar, sem replicar, sem duvidar, sem resistir; mas são estátuas de murta que, em levantando a mão e a tesoura o jardineiro, logo perdem a nova figura, e tornam à bruteza antiga e natural, e a ser mato como dantes eram. É necessário que assista sempre a estas estátuas o mestre delas: uma vez, que lhes corte o que vicejam os olhos, para que creiam o que não veem; outra vez, que lhes cerceie o que vicejam as orelhas, para que não deem ouvidos às fábulas de seus antepassados; outra vez, que lhes decepe o que vicejam as mãos e os pés, para que se abstenham das ações e costumes bárbaros da gentilidade. E só desta maneira, trabalhando sempre contra a natureza do tronco e humor das raízes, se pode conservar nestas plantas rudes a forma não natural, e compostura dos ramos (VIEIRA, 1957, p. 5-6).

Desses artistas, cenas estranhas e inimigas "de toda innovación, de todo lo que rompe com las reglas y normas [...] todo lo académico es conservador, observante, obediente de reglas" (CARPENTIER, 2010, p. 337). Emergem processos tradutórios da relação, mediação ou incorporação do Outro sempre colocando lado a lado o passado com o presente. Chamaremos, por conveniência e também mediação com outros estudos, esse desconhecido fenômeno artístico de barroquismo:

El barroquismo americano se acresce com la criolledad, con el sentido de criollo, con la conciencia que cobra el hombre americano, sea hijo de 
blanco venido de Europa, sea hijo de negro africano, sea hijo de indio nacido en el continente [...] la conciencia de ser otra cosa, de se uma cosa nueva, de ser una simbiosis, de ser um criollo; y el espíritu criollo de por sí es um espíritu barroco (CARPENTIER, 2010, p. 347).

Esses artistas não se assentam no processo criatório com "épocas assentadas, plenas de sí mismas, seguras de sí mismas: el Barroco, en cambio, se manifiesta donde hay transformación, mutación, innovación" (CARPENTIER, 2010, p. 344). Seriam esses barbantes e essas vozes "filhos" do "espírito criollo de por sí es um espíritu barroco", lugares do real maravilhoso: "todo lo insólito, todo lo assombroso, todo lo que se sale de las normas estabelecidas es maravilloso" (CARPENTIER, 2010, p. 348). Do desenraizamento e da errância, àqueles se propondo a intermináveis travessias pelos domínios porosos e permeáveis do signo híbrido. Esse desconhecido nos afrontando com sua multifacetada aparência. Analisamos escritos, vozes ou imagens?

Por empréstimo da poética de Franz Fanon (2008, p. 08), "quando conta de modo comovente o drama do homem discriminado [...] poesia de alta qualidade...”, repudiamos as "verdades decisivas" em direção a estudos artísticos mais humanistas. Aparentemente, à guisa dos preceitos do materialismo histórico infiltrante nos estudos da filosofia da linguagem, as reflexões sobre os barbantes arrolados tangenciam a compreensão de que "tudo que é ideológico possui um valor semiótico" e portando, "a palavra funciona como elemento essencial que acompanha toda criação ideológica, seja ela qual for” (BAKHTin, 2006, p. 29-37). Sabemos, porém, os limites das transposições teóricas para fenômenos estéticos tão ausentes nas cenas acadêmicas. Daí, admitimos nossa des-autoridade tradutória (CLIFFORD, 1998) para esses regimes de sentidos. Resolvemos não explicar e nem interpretar definitivamente. Sugerimos uma afecção escrito-epistêmica-artística chamada de amizade com o devido empréstimo de Agamben:

O amigo não é um outro eu, mas uma alteridade imanente na mesmidade, um tornar-se outro do mesmo. No ponto que eu percebo a minha existência como doce, a minha sensação é atravessada por um com-sentir que a desloca e exporta para o amigo, para o outro mesmo. A amizade é essa des-subjetivação no coração mesmo da sensação mais íntima de si (AgAmben, 2009, p. 90).

A pesquisa compreende que as redes de afetos construídas não significaram apenas recordações descritivas sem as devidas referências dos "percalços", nas atividades de campo realizadas. Certo engessamento do meio acadêmico elitistaconservador persistente reproduz fronteiras abissais de perspectiva macro, para legitimar, por exemplo, faixas de transição entre uns e outros; entre as culturas tradicionais reconhecidas comumente como folclore e a aquelas que detêm maior atualização e prestígio (Pires FerreIra, 2010). 
Na busca de vozes e memórias para subsidiarem essa pesquisa deparamo-nos com desdobramentos que precipitadamente poderíamos subtraí-los, aqui, mas achamos pertinente transformar experiência em texto e detectar a eficácia social das ações de forma analítica (Peirano, 2014). Dirigimo-nos ao município de Eldorado dos Carajás, estado do Pará, para diálogo com alguns cordelistas. Em um desses cenários junto a uma habitação cercada de "pés de laranja", ao nos apresentarmos como pesquisadores da universidade, ouvimos: "Não quero falar com gente de universidade!". Apesar das tentativas de apaziguamento da situação, o interlocutor insistia na incapacidade da "universidade" em desenvolver escuta e descrições dignas para algumas vozes. Isso poderia ser ignorado, mas dividimos algumas preocupações: o que teria feito a "universidade" para aquele homem? Resolvemos de modo rudimentar tracejar uma hipótese.

O "fazer cordel", em muitos segmentos universitários, inclusive em certos espaços abissais da nossa universidade, geralmente está associado a uma prática "rural" relegada ao atrasado, ao menor, ao popular. Um fazer estético "diminuído". O testemunho nos fez relembrar toda "sorte" de bricolagens com os estilhaços de uma ocidentalização frustrante espalhados: artes, religiões. Trocas simbólicasculturais desperdiçadas pela arrogância e pelas diferentes versões do preconceito. Por uma dessas encruzilhadas de nossas pesquisas, as ciências unas e absolutas viram objeto de derrisão para o crítico cordelista de Eldorado dos Carajás. Fomos, enfim, convidados a fazer algo de mais sério - esperamos que esse texto o faça e a nos afastar e retirar dos "pés de laranja...".

\section{Referências}

Adorno, Theodor W. O que significa elaborar o passado. Educação e emancipação. Porto Velho: Editora Universidade Federal De Rondônia, 1995.

Agamben, Giorgio. O que é o Contemporâneo? E outros ensaios. Tradução de Vinícius Encastro Honesko. Chapecó, Santa Catarina, Brasil: Argos, 2009.

BAKHTIn, Mikhail Mikhaŭlovich et al. Marxismo e filosofia da linguagem: problemas fundamentais do método sociológico na ciência da linguagem. São Paulo: Hucitec, 1979.

Benjamin, Walter. Sobre o conceito de História. In: Magia e Técnica, arte e política: ensaios sobre literatura e história da cultura. São Paulo: Brasiliense, 1996.

Calvino, Italo. As cidades invisíveis. São Paulo: Companhia das Letras, 1990.

CArpentier, Alejo. América, la imagen de una conjunción. Rubí (Barcelona): Arthropos Editorial. 2004.

Carpentier, Alejo. Lo barroco y real maravilloso. Disponível em: https: //circulodepoesia.com/2010/12/lo-barroco-y-lo-real-maravilloso-conferencia-dealejo-carpentier/. Acesso em: 02 de jan. 2015. 
Clifford, James. "Sobre a autoridade etnográfica". In: A experiência etnográfica. A antropologia e literatura no século XX. Rio de Janeiro: UFRJ, 1998.

Fanon, Frantz. Peles negras, máscaras brancas. Tradução de Renato da Silveira. Salvador: EDUFBA, 2008.

Foucault, M. A vida dos homens infames. Estratégia, poder-saber. Ditos e escritos IV. Rio de Janeiro: Forense Universitária, p. 203-222.

Foucault, M. A ordem do discurso. São Paulo: Edições Loyola, 1996.

Glissant, Édouard. Introdução a uma poética da diversidade. Tradução Enilce do Carmo Albergaria Rocha. Juiz de Fora: Ed. UFJF, 2005.

Glissant, Édouard. Poetics of Relation. Translated by Betsy Wing. United States of America: University of Michigan Press, 1997.

Hur, Domenico Uhng. Memória e Tempo em Deleuze. Multiplicidade e Produção. Athenea Digital, Barcelona, p.179-19o, 2013.

Orlandi, Eni Pulcinelli. As formas do silêncio: no movimento dos sentidos. Campinas: Editora da Unicamp, 1995.

Peirano, Mariza. Etnografia não é método. Horizontes Antropológicos, Porto Alegre, v. 20, n. 42 , p. $377-391,2014$.

Pires Ferreira, Jerusa. Cultura das bordas: edição, comunicação, leitura. São Paulo: Ateliê Editorial, 2010.

Possas, Hiran de Moura et al. "Recifrando" Acordes: Marabá das Bordas. Revista Boitatá. Revista do GT de Literatura Oral e Popular da ANPOLL, Londrina, $\mathrm{n}^{\circ}$ 21, 2016.

QueIroz, Renato da silva. O herói-trapaceiro. Reflexões sobre a figura do trickster. São Paulo: Tempo Social. Revista Social, 1991.

RamA, A. Transculturación narrativa en América Latina. México: Siglo XXI, 1982.

RolNik, Suely. Cartografia sentimental: transformações contemporâneas do desejo. Porto Alegre: Sulina/Editora da UFRGS, 2014.

Seligmann-Silva, Márcio. Narrar o trauma: a questão dos testemunhos de catástrofes históricas. Psicologia clínica, Rio de Janeiro, v. 2o, n. 1, p. 65-82, 2008.

Serres, Michel. Filosofia Mestiça. Tradução de Maria Ignez Duque Estrada. Rio de Janeiro: Nova Fronteira, 1993.

SpIVAK, Gayatri Chakravorty. Pode o subalterno falar? Trad. Sandra Regina Goulart Almeida; Marcos Pereira Feitosa; André Pereira. Belo Horizonte: Editora da UFMG, 2010. 
Thomson, Alistair. Recompondo a memória: questões sobre a relação entre a história oral e as memórias. Projeto História, São Paulo, n. 15, p. 51-84, abr. 1997.

Vieira, António. "Sermão do Espírito Santo". In: Sermões. São Paulo: Editora das Américas, vol. 5, p. 205-55, 1957 [1657].

Viveiros De Castro, E.; Sztutman, R. (Org.). Eduardo Viveiros de Castro - Série Encontros. Rio de Janeiro: Azougue, 2008.

Viveiros De Castro, E. A inconstância da alma selvagem e outros ensaios de antropologia. São Paulo: Cosac Naify, 2001.

Viveiros De Castro, E. Metafísicas canibais: elementos para uma antropologia pós-estrutural. São Paulo: Cosac Naify, 2015.

Viveiros De Castro, E. et al. Abaeté, rede de antropologia simétrica: entrevista com Marcio Goldman e Eduardo Viveiros de Castro. Cadernos de Campo (USP), São Paulo, v. 14/15, p. 177-19o, 2006.

TupiAssú, Amarílis. O signo Max. Disponível em http://www.culturapara.art.br/ maxmartins/opiniao_o1.htm. Acesso em: 05 jan. 2015.

Zizek, Slavoj. Sonhando perigosamente com Slavoj Zizek. Disponível em http://umbigodascoisas.com/2012/12/o2/slavoj-zizek-entrevista/. Acesso em 19 set. 2014.

Zumthor, Paul. Performance, recepção e leitura. Tradução de Jerusa Pires Ferreira e Suely Fenerich. São Paulo: Hucitec/Educ, 2000.

Zumthor, Paul. A letra e a voz: a "literatura" medieval. Tradução de Amálio Pinheiro/Jerusa Pires Ferreira. São Paulo: Companhia das Letras, 1993.

Zumthor, Paul. Tradição e esquecimento. Tradução de Jerusa Pires Ferreira e Suely Fenerich. São Paulo: Hucitec, 1997.

Zumthor, Paul. Performance, recepção e leitura. Tradução de Jerusa Pires Ferreira e Suely Fenerich. São Paulo: Hucitec/Educ, 2000.

\section{Fontes orais}

Araújo, Valdir. Entrevista Oral [gravada] realizada por Larissa Sousa. Palestina do Pará, 27 Març. 2017. 1h 12 min.

Lorota, Manuel. Entrevista Oral [gravada] realizada por Monica Almeida. Palestina do Pará, 27 Març. 2016. 1h 12 min.

Lorota, Manuel. Entrevista Oral [gravada] realizada por Hiran de Moura Possas e Monica Almeida. Palestina do Pará, 27 Març. 2017. $1 \mathrm{~h} 12 \mathrm{~min}$.

Silvandira. Entrevista Oral [gravada] realizada por Monica Almeida. Palestina do Pará, 27 Març. 2017. 1h 12 min. 
Seu Poeta. Entrevista Oral [gravada] realizada por Aline da Silva e Silva . Parauapebas (PA Palmares II), 26 Out. 2017. 1h oo min.

Recebido em 9 de outubro de 2018.

Aprovado em 20 de outubro de 2019.

\section{Resumo/Abstract/Resumen}

Barroquismos em cordéis de testemunho: migrações, massacres e resistências nos sul e sudeste do Pará - Brasil

\section{Hiran de Moura Possas}

O escrito é parte da memória de pesquisa objetivando analisar folhetos de cordéis acompanhados de entrevistas com as autorias. Seria um estudo das manifestações do que chamaremos de literatura "subalterna" oral-escrita refratando universos simbólicos da região sul e sudeste do Pará: Marabá; Brejo Grande do Araguaia; Palestina do Pará, Eldorados dos Carajás e Projeto de Assentamento Palmares II (Município de Parauapebas). Desse exercício epistêmico de aprumada escuta, fundamentado por alguns pressupostos da história oral acompanhados de breves ensaios interpretativos, emergem fragmentos memoriais advindos, dentre outros, da luta pela terra e da Guerrilha do Araguaia. A simples descrição e o reconhecimento dessas texturas não obviamente significarão desnaturalizar, por completo, certos discursos depreciativos impostos aos artífices de manifestações artísticas incompreensíveis aos estudos culturais e/ou literários mais intolerantes, mas Manoel Lorota (Palestina do Pará), Silvandira (Vila Santa Rita/distrito do município de Brejo Grande do Araguaia), Valdir de Araújo (Eldorado dos Carajás) e "Seu Poeta" (P A Palmares II) conjugam, pelas interfaces da letra com a voz, e pelas redes de afetos agenciadas com essa pesquisa, outras artes e histórias, que estrategicamente são alijadas e depreciadas pelos exercícios acadêmicos classificadoreshierarquizantes.

Palavras-chave: cordel, movimentos sociais, memória, barroquismo.

Baroquisms in cordel stories: migrations, massacres and resistance in the south and southeast of Pará - Brazil

\section{Hiran de Moura Possas}

The writing is part of the research report which aims to analyse cordel booklets, accompanied by interviews with their authors. It is a study of the manifestations of what we will call "oral-written"subaltern literature refracting symbolic universes of the south and southeast of Pará: Marabá; Brejo Grande do Araguaia; Palestina do Pará, Eldorados dos Carajás and Palmares II Settlement Project (Parauapebas Municipality). From this epistemic exercise of skilful listening, based on 
some presuppositions of oral history accompanied by brief interpretive essays, fragments of memory emerge, among others, from the struggle for land and the Araguaia Guerrilla. The simple description and recognition of these textures will obviously not mean totally denaturalising certain derogatory discourses imposed on the artisans of artistic manifestations incomprehensible to the most intolerant cultural and / or literary studies; nevertheless, Manoel Lorota (Palestine of Pará), Silvandira (Vila Santa Rita, municipal district of Brejo Grande do Araguaia), Valdir de Araújo (Eldorado dos Carajás) and "Seu Poeta" (P A Palmares II) ) combine, via the interface of written and spoken words, and via the networks of feelings associated with this research, other arts and histories, which are strategically alienated and depreciated by classifying-hierarchical academic teams.

Keywords: cordel; social movements; memory, baroque.

\section{Barroquismos en cordeles de testimonio: migraciones, masacres y resis- tencias en el sur y sureste de Pará - Brasil}

\section{Hiran de Moura Possas}

Este trabajo es parte de una memoria de investigación que tiene como objetivo analizar folletos de cordeles, acompañados de entrevistas con sus autores. Sería un estudio de las manifestaciones de lo que llamaremos literatura "subalterna"oralescrita refractando universos simbólicos de la región sur y sudeste del Pará: Marabá, Brejo Grande do Araguaia; Palestina do Pará, Eldorados dos Carajás y Projeto de Assentamento Palmares II (Municipio de Parauapebas). De éste ejercicio epistémico de aplomada escucha, fundamentado en algunos de los presupuestos de la historia oral, con la ayuda de breves ensayos interpretativos, emergen fragmentos memorables provenientes, entre otros, de la lucha por la tierra y de la guerrilla del Araguaia. La simple descripción y el reconocimiento de esas texturas no significarán desnaturalizar, por completo, ciertos discursos despectivos impuestos a los artífices de manifestaciones artísticas incomprensibles a los estudios culturales o literarios más intolerantes; mas Manoel Lorota (Palestina do Pará), Silvandira (Vila Santa Rita/distrito do município de Brejo Grande do Araguaia), Valdir de Araújo (Eldorado dos Carajás) y "Seu Poeta" (P A Palmares II) conjugan, a través de las interfaces de letra y voz, y a través de las redes de afectos agenciadas durante esta investigación; otras artes e historias, que son estratégicamente alienadas y depreciadas por los ejercicios académicos clasificadores e jerarquizantes.

Palabras clave: cordel, movimientos sociales, memoria, barroquismo. 